\title{
Restrictive Relative Constructions in Pesh: A Predominantly Internally-Headed Relative Clause Language
}

\author{
Claudine Chamoreau
}

\begin{abstract}
In this chapter, I offer the first description of restrictive headed relative constructions in Pesh, a Chibchan language spoken in Honduras. This language follows three relativization strategies: 1 ) internally-headed relative clauses in which the head nominal of the relative clause, which is a core argument or a genitive, occurs inside the relative clause. This is the most frequent and primary strategy in Pesh, as it is used to relativize subjects; 2) externally-headed relative clauses in which the head nominal, which has a peripheral role in the relative clause, occurs outside the relative clause, being represented in the relative clause by a gap; and 3) relative clauses introduced by a WH-word that functions as a relative; only locative WH-words piah 'where' and pikan 'where, in which direction' occur. The distribution of the three relative clauses in Pesh clearly responds to accessibility restrictions on specific functions. Further, this chapter explores the relation between relative strategies and degree of finiteness. Internally-headed relative clauses and externally-headed relative clauses are less finite and show some nominalized features in the scalar phenomenon of nominalization, since the marker that obligatorily occurs at the end of the relative construction in internally-headed relative clauses and at the end of the relative clause in externally-headed relative clauses is a case or the topic enclitic marker prototypically used at the end of noun and postpositional phrases. In contrast, relative clauses bearing a WHword are most finite, and their subordinate feature is marked by a subordinator at the end of the verb.
\end{abstract}




\title{
Restrictive Relative Constructions in Pesh: A Predominantly Internally-Headed Relative Clause Language
}

\author{
Claudine Chamoreau
}

\subsection{Introduction}

In his definition, Lehmann (1986: 664) introduces the different components included in relative constructions: "A relative construction is a construction consisting of a nominal (or a common noun phrase, in the terms of categorial grammar) (which may be empty) and a subordinate clause interpreted as attributively modifying the nominal. The nominal is called the head and the subordinate clause the relative clause ( $\mathrm{RC}$ ). The attributive relation between head and RC is such that the head is involved in what is stated in the clause". This definition is broad as it may be applied to both headed and headless and to restrictive and non-restrictive (or appositive) RCs. Lehmann's proposition is schematized in (1):

(1) $\left[[\text { (head) nominal }]_{\mathrm{RC}}\right]_{\mathrm{R} . \text { construction }}$

[[head nominal $\left.]_{\mathrm{RC}}\right]_{\mathrm{R} . \text { construction }}$

In (1), the position of the elements follows the order of presentation in Lehmann's definition inside the relative construction. However, no presuppositions are introduced about the order or the type of relation between the RC and the head nominal, also known as the domain nominal (Andrews 2007: 214).

In this chapter, I focus on restrictive headed RCS in Pesh, ${ }^{1}$ the northernmost of the Chibchan languages, and the only one spoken in Honduras. This chapter offers the first description and analysis of this type of construction in Pesh, which has not been studied in the scanty literature available on this language (Conzemius 1928, Holt 1999). The first goal is to show that the syntactic role of the head nominal within the RC is important for distinguishing three types of restrictive RC. The first type, an internally-headed RC (henceforth IHRC), occurs when the head nominal has the role of a genitive (possessee) or a core argument in the RC. The enclitic that occurs at the end of the relative construction may be a case marker or the topic marker. It corresponds to the syntactic role of the head nominal in the matrix clause, as in (2) where the accusative enclitic =ra marks the fact that the head nominal korta 'the woman' is the primary object (PO) in the matrix clause regardless of its role in the RC. In (2) the nominal korta 'the woman' is the A in the RC. This behavior coincides with Comrie's description of an IHRC (1989 [1981]: 145).

\footnotetext{
${ }^{1}$ For a study of headless RCs in Pesh see Chamoreau (2020a).
} 
(2) tàsmà kàpàn kàpàn kórtà tayè? kàtfềmirà wífkari

$\begin{array}{llllll}\text { tas }=m a & {[\text { kapan }} & \text { kapan } & \text { korta } & \text { ta-ye? } & \varnothing \text {-ka-tfã- } \varnothing \text {-pi]=ra } \\ 1_{\text {PRO }}=\text { TOP } & \text { morning } & \text { morning } & \text { woman } & \text { POSS1-small } & \text { O3SG-APPL:R-see-s3sG-FUT=ACC }\end{array}$

$\emptyset$-wif-k-a-ri
O3sG-give.03-K-s1SG-PST
'I entrusted him to the woman who will take care of my son every morning.' $\{\text { Txt }\}^{3}$

The second type, an externally-headed RC (henceforth EHRC), is in complementary distribution with relativization by means of an IHRC, since an EHRC is used when the head nominal has a peripheral role (oblique or adjunct) in the RC. The case marker that obligatorily occurs at the end of the RC corresponds to the syntactic role of the head nominal in the RC, as in (3); the comitative/instrumental enclitic =yo indicates that the head nominal kukarska 'the hoe' is the instrument in the RC regardless of its role in the matrix clause, an 0 in (3). The nominal that functions as the head of the RC occurs outside the RC, being represented in the $\mathrm{RC}$ by a gap marked by _ in the examples of EHRCS.

(3) kúkàrskà yèrhá tàkiíyó úhàrí

$\begin{array}{llll}\text { kukarska } & {[\text { ye?-ha }} & \text { ta-ka- } \varnothing \text {-i }]=\text { yo } & \emptyset \text {-uh- } a-r i \\ \text { hoe } & \text { small-NMLZ } & \text { 01-hit-s3sG-PST=INSTR } & \text { o3sG-hide-s1sG-PST } \\ \text { 'I hid the hoe with which the small boy hit me.' } & \end{array}$

The third type is the RC introduced by a WH-word that functions as a relative pronoun (WH$\mathrm{RC}$ ). It is less common and only occurs when the head nominal has the syntactic role of the locative adjunct in the RC regardless of its role in the matrix clause. In (4) the nominal taka?o 'my house' is the o in the matrix clause. The head nominal that functions as the head of the RC occurs outside the RC, as in (4) ta-ka?o 'my house'. The RC is introduced by the clause-initial WH-word pi-ah 'where' which shows its semantic role in the RC. The fronting of the constitutent indicating the locative role is indicated by a trace, in the original position, marked by a $t$ (Comrie 1998: 64-67). The RC is obligatorily marked by a subordinator encliticized at the end of the predicate, usually a verb, for example the uncertainty subordinator $=$ sri in (4).

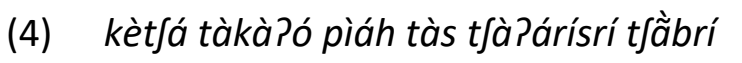
$\begin{array}{llllll}\text { ket } \int a & \text { ta-ka?o } & \text { [pi-ah } & \text { tas } & \text { t } & \text { t } \boldsymbol{p} a-a-r i=s r i] \\ \text { yesterday } & \text { POSS1-house } & \text { place-NMLZ } & 1_{\text {PRO }} & & \text { be_there-S1SG-PST=UNCRT }\end{array}$
$\varnothing$-tfã-ber-i
O3SG-See-S1PL.EXCL-PST
'Yesterday, we saw the house where I was born.' $\{$ Txt $\}$

\footnotetext{
${ }^{2}$ In the examples in Pesh, the first line represents a simple transcription (the accents indicate types of stress or tone, we currently do not know exactly which, and the tilde is for the nasal vowel). The second line is the phonological transcription (no stress or tone are transcribed); the third line gives the morpheme-bymorpheme glosses; the fourth line provides an English translation.

${ }^{3}\{\mathrm{Txt}\}$ indicates that the example comes from a textual natural corpus. Examples that come from elicited data bear no special mark.
} 
IHRCS employ a non-reduction strategy, also called circumnominal RC (Comrie 1989 [1981]: 146, Lehmann 1986: 665), whereas EHRCS and WH-RCS are described as reduction strategies. In Pesh, they are embedded and always postnominal.

The distribution of the three relativization strategies in Pesh clearly responds to the accessibility restrictions on specific functions summarized in Table 9.1: argument and genitive with IHRCS, oblique and adjunct (comitative, instrumental, locative, and object of comparison) with EHRCS, and locative with WH-RCS. This distribution shows a specific position for locative role as the WH-RC is representated only by this role and it is the sole one that is present in two types of constructions. The IHRC is the predominant and primary strategy used in Pesh because it corresponds to the relativization of the subject function.

\section{TABLE 9.1. Accessibility to different relativization strategies}

$\begin{array}{lcccccccc}\text { Strategy } & \text { S/A } & \text { PO } & \text { SO } & \text { GEN } & \text { INSTR } & \text { COM } & \text { O.COMP } & \text { LOC } \\ \text { IHRC } & + & + & + & + & - & - & - & - \\ \text { EHRC } & - & - & - & - & + & + & + & + \\ \text { WH-RC } & - & - & - & - & - & - & - & +\end{array}$

PO: primary object; so: secondary object; O.cOMP: object of comparison

The distribution found in Pesh matches Lehmann's (1986: 666-668) hierarchy composed of several sub-hierarchies: firstly, functions that modify verbs as shown in (5a); and secondly, functions that modify nouns, in (5b). This complex hierarchy explains why core arguments and genitives that have a higher position in the two sub-hierarchies share the same IHRC strategy (in bold) and why obliques and adjuncts that have a lower position share the same EHRC strategy (in roman). The locative role appears in roman and in italics because it can be relativized via two different strategies, the EHRC (in roman) and the WH-RC (italics).

(5) a. S/A - SO - PO - OBL - ADJUNCT (LOC)

b. GEN - O.COMP

The second goal of this chapter is to show the correlation between the degree of finiteness and the type of RC. A common characteristic of RCS is to be subordinated (Comrie 1989 [1981]: 142-144, Lehmann 1986: 666, Andrews 2007: 206, 231-232) while at the same time subordinate RCs have been described as nominalized to varying degrees. This type of grammatical nominalization may be defined as a syntactic process "via which a finite verbal clause [...] is converted into a noun phrase" (Givón 2016: 272). From this perspective, finiteness is evaluated on the relative construction, not only on the verb or on the RC (Chamoreau \& Estrada 2016). There is a continuum where several degrees may arise between prototypical finite verbal clause and prototypical noun phrase (Givón 2001: 25). Pesh has an interesting way of distinguishing two degrees of finiteness as the finite WH-RC displays a clearly different type of structure from the most nominalized IHRC and EHRC. The RC with WH-word is finite and its subordinate feature is marked by a subordinator at the end of the verb. In contrast, in IHRCS and EHRCS, the marker that obligatorily occurs at the end of the relative construction in IHRCS and at the end of the RC in EHRCS (see Sections 9.3 and 9.4 for descriptions) is a case or the topic enclitic marker prototypically used at the end of noun phrases and postpositional phrases. Even if the verbs in (2) and (3) display finite features (pronominal and tense markers), the most nominalized features of IHRCS and EHRCS are 
inferred from the occurrence of case or topic enclitic markers. This nominal property is exhibited by the relative construction that functions in the matrix clause as an NP or a PP.

As the internally and externally-headed RCS are in complementary distribution and possess similar characteristics, I will describe them first and then discuss the particular features of the RC introduced by a WH-word. The chapter is thus organized as follows: Section 9.2 provides a general overview of the main grammatical features, focusing on topics necessary for understanding the processes described in the following Sections. Section 9.3 presents the features of the IHRC, and Section 9.4 those of the EHRC in Pesh. Section 9.5 discusses the specificities of the RC introduced by a WH-word. Section 9.6 addresses the question of the degrees of finiteness in the different strategies and concludes the chapter.

\subsection{Main features of Pesh}

Pesh (Pech, Paya, ISO pay) is the northernmost of the sixteen living Chibchan languages (Constenla Umaña 2012, Quesada 2007: 33), and the only one spoken in Honduras. Pesh is classified as the only language in the family that constitutes a unique branch; it is the sole language that does not belong to Core Chibchan (see Figure 9.1).

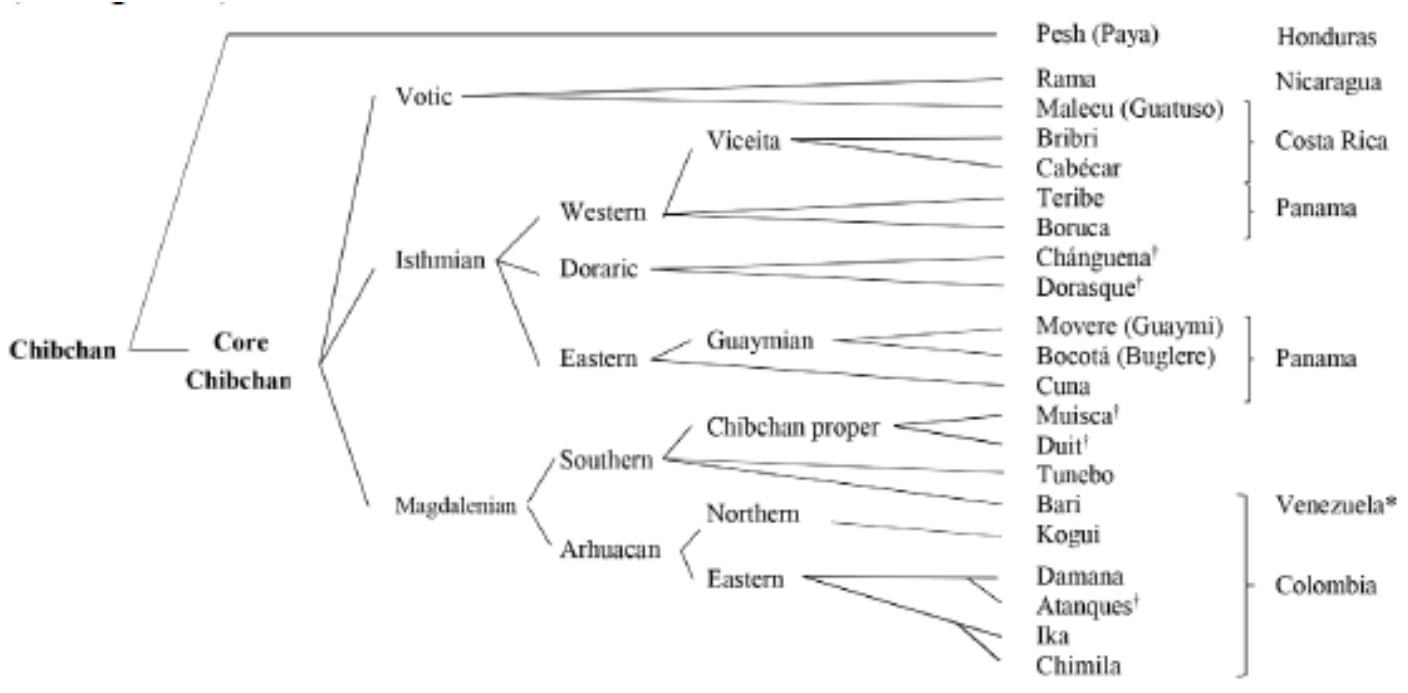

FIGURE 9.1. Chibchan language family (adapted from Constenla Umaña 2012)

\subsubsection{Basic Morphosyntactic Features}

Pesh exhibits the main features associated with a verb-final, or more precisely an AOV constituent order, language. Thus the respective roles of the NPs preceding the verb are indicated by their position, as in (6) where the A patasuwama 'our grandmothers' precedes the o munia 'munia'. ${ }^{4}$ Postpositional phrases (PP) usually appear before the verb, and are marked by an enclitic marker, as the locative enclitic marker $=y \tilde{a}$ in (7).

\footnotetext{
${ }^{4}$ The munia is a yucca drink.
} 
(6) pàtàsùwámà mừnyà kī’ràn
A
pa-ta-suwa=ma
o v
INCL-POSs1-grandmother=TOP munia O3sG-make-S3PL-PFV
'Our grandmothers make munia.' $\{$ Txt $\}$

(7) wàhấnấ nã̀áwá, pầhàkààs pé?pá

\begin{tabular}{|c|c|c|c|c|}
\hline LOC & v & 0 & & v \\
\hline$w a h a=y \tilde{a}$ & $n \tilde{a}-a-w a$ & pãh & $a k a=a s$ & $\varnothing$-pe?-pa \\
\hline mountain $=\mathrm{LOC}$ & go-S1SG-PFV & wood & big $=I N D F$ & O3SG-bring-s1sG.FUT \\
\hline
\end{tabular}

The properties of NPs are those typically associated with head-final characteristics. The possessor occurs before the possessee, as in (8) the possessor katfara-ha 'stream' is preposed to the possessee $a$-tah 'foot' which is obligatorily marked by a possessive marker. The numeral and the article are always postposed, as in (7) and (8).

(8) krís yèkōrtā pōg t tirî́wấ? kāt áráhá àtấnã
kris ye korta pok tja-er-ri-wã
katJara-ha
once small woman two be_there-S3PL-PST-PRF stream-NMLZ
$a-\operatorname{tah}=y \tilde{a}$
POSS3SG-foot=LOC
'Once, two young women were at the foot of a stream of water.'

Pesh features a split alignment that depends on the way the arguments are expressed. It has a nominative-accusative alignment for agreement affixes and an optional ergativeabsolutive or tripartite alignment for flagging free NP arguments (Chamoreau 2021). ${ }^{5}$ Pesh has compulsory verb agreement. This is a double marking language. The sole argument of an intransitive verb, as in (9), and the two arguments of a monotransitive verb, as in (10), are obligatorily encoded in the verb.

Intransitive verb

(9) ké yùimã̀yh kàhnì tèjkrí

ke yui mã̀h kahni tef-k-er-i
already moon three four walk-K-s3PL-PST
'Already three or four months had passed.' $\{$ Txt $\}$

\footnotetext{
${ }^{5}$ In independent and matrix clauses, the alignment is ergative-absolutive in the Carbon variety and tripartite (subject in intransitive verbs, ergative and accusative in transitive verbs) in the Culmi variety as in this latter, the subject of the intransitive verb is never marked (Chamoreau 2019). For the term 'optional', see McGregor and Verstraete 2010 and Chamoreau 2021.
} 
Monotransitive verb

(10) kōrhtālèrmã̀: yùkú àtè’ $w$ àt $t e^{h} r \grave{a}$

korta-ler=ma yuku a-tewa a-tJah-er-wa

woman-PL=TOP meat POSs3sG-chili O3sG-put-s3PL-PFV

'The women add chili to the meat (the chili of the meat).' $\{$ Txt $\}$

In the case of a ditransitive verb, Pesh exhibits a secundative alignment for indexing: the participant that can be encoded is the PO (11) and (12), while the so cannot be encoded (Chamoreau 2017a).

Ditransitive verb

(11) tàtùs tàs tàsùwá wíkkrí

$\begin{array}{llll}\text { ta-tus } & \text { tas } & \text { ta-suwa } & \varnothing \text {-wif-k-er-i } \\ \text { POSS1-father } & 1_{\text {PRO }} & \text { POSS1-grandmother } & \text { O3sG-give.03-K-S3PL-PST }\end{array}$

'My parents entrusted me to my grandmother.' $\{$ Txt $\}$

(12) tàkàkì tàsùwárá tã̀yhî́
ta-kaki
ta-suwa=ra
ta-ãyh- $\varnothing-i$
POss1-mother POss1-grandmother=ABS
01-give.01/2-s3sG-PST
'My mother entrusted my grandmother to me.'

Pesh is a case-marking language with six case enclitics, listed in (13).

(13) Phrasal case enclitics

=ya Ergative

$=r a \quad$ Absolutive (=ro, a dialectal variation used in the Carbon dialect)

$=y \tilde{a} \quad$ Locative

=yo Comitative/instrumental

$=k a n$ Similative (=ken, a dialectal variation used in the Carbon dialect)

=ri Temporal/manner

Case-marking enclitics are phrase final, as in (14).

(14) ispáràh àmùktá tẽ̀náhyó kàtũ̀fkáwá
isparah amukta tẽnah=yo katũf-k-a-wa
machete rotten heavy=INSTR work-K-S1SG-PFV

'I worked with the rotten and heavy machete.' $\{$ Txt $\}$

An optional ergative and absolutive or accusative enclitic marking is displayed (see note 5); its use is motivated by information structure, in particular the focusing of a participant (a precise study is in progress). For flagging, the A of a transitive verb may be indicated by the ergative marker $=y a$, as in (15).

(15) ấ ár ${ }^{h} w$ rò kì:ná wisã̀ àkákiyá

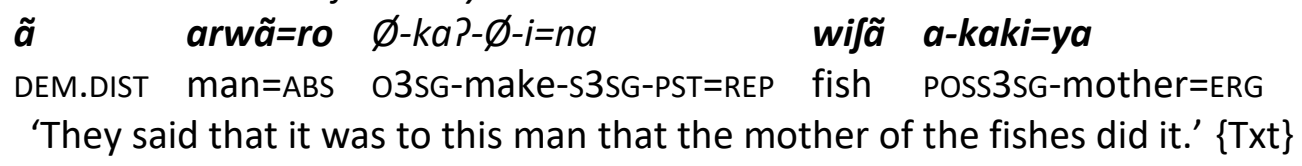


In the variety of Carbon, the $\mathrm{s}$ of an intransitive verb, as in (16), the o of a monotransitive verb (17), and both 0 in a ditransitive verb may all be marked by the absolutive case marker $=r o$, as we also observe in the case of the so in (12) and the PO in (15). In a ditransitive verb, Pesh exhibits a neutral object alignment for flagging (see note 5 for the tripartite alignment in the Culmi variety).

(16) àkàwàyó tauwèhi ĩà ùrùrō tāwārkwá

$\begin{array}{llll}a-k a w a=y o & \text { tawe }-\varnothing-h i & \tilde{l} & \text { a-puru=ro } \\ \text { POSs3sG-spouse=com } & \text { go_up-s3sG-PST } & \text { DEM.PROX } & \text { POSS3sG-canoe=ABS }\end{array}$

ta-war-k- $\varnothing-w a$

MIDD-capsize-K-S3SG-PFV

'He went up with his spouse, and this canoe capsized.' $\{T x t\}$

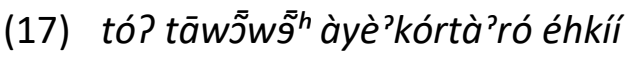
to?
ta-wãwãh
a-ye
korta $=$ ro
$\varnothing$-eh-k-i-i
DEM.MED POSS1-grandfather POSs3-small
woman=ABS O3SG-repair-K-S3SG-PST

'My grandfather healed the girl.' $\{T x t\}$

\subsubsection{Topic Enclitic $=m a$}

The topic enclitic $=m a$ is optional and is usually correlated with thematic discontinuity or referent complexity, that is, with the need to encode the topic to maintain discourse coherence (Chamoreau 2020b). It may indicate a continuing, shifted or contrastive topic. It is also used for frame-setting topics. The topic is usually left-dislocated; when various arguments are attested in a sentence, it occurs as the first NP. In (18), the syntactic 0 sira=ma 'the meal' is left-dislocated and marked by the topic marker, since this NP represents a shift of the topic. It is positioned before the A juana.

(18) siràmà juanayá kì?í

$$
\begin{array}{lll}
\text { sira }=\text { ma } & \text { juana=ya } & \varnothing-k a P-i-i \\
\text { meal=TOP } & \text { J.=ERG } & \text { O3sG-make-s3sG-PST }
\end{array}
$$

'As for the meal, Juana made it.' $\{$ Txt $\}$

When =ma is used in a subject NP as in (10) or an object NP as in (18), it is impossible to use the ergative or absolutive case marker. The topic marker $=m a$ is used alone with the constituent that expresses a core argument. In contrast, in a PP, when the topic is an oblique or adjunct constituent, such as the locative in (19), the string with the case enclitic and the enclitic $=m a$ are obligatory.

(19) ấyấmà tàsùwáyó àkàtífkárí

$$
\begin{array}{lll}
\tilde{a}=y \tilde{a}=m a & \text { ta-suwa=yo } & a-k a t i \int-k-a-r i \\
\text { DEM.DIST=LOC=TOP } & \text { POSs1-grandmother=COM } & \text { REFL/RECP-bring.up-K-S1SG-PST } \\
\text { 'There, I was raised by my grandmother.' }\{\text { Txt }\}
\end{array}
$$




\subsection{Internally-Headed Relative Clauses}

In Pesh, the IHRC constitutes the most frequent and the primary strategy of forming RCS, since this type of construction is the only one used to relativize the subject. Comrie (1989 [1981]: 145) treats this construction as a relative construction in which "the head noun remains expressed within the $\mathrm{RC}$, in the usual form for a noun of that grammatical relation within a clause, and there is no overt expression of the head in the main clause... The fact that a clause is functioning as a noun phrase referring to the head is even clearer in Diegueño, where the clause in question can take the appropriate suffix to indicate its syntactic role in the main clause." IHRCS constitute a subtype of the non-reduction strategy (Comrie \& Kuteva 2005), in which the head nominal is a constituent of the RC (Basilico 1996: 499).

In Pesh, relativization by means of an IHRC is used when the head nominal either has the function of a genitive (possessee) or is a core argument in the RC (most commonly the subject). When this happens, the phrasal marker that occurs at the right edge of the relative construction (which coincides with the right boundary of the RC, see Section 9.3.3.) indexes the syntactic role of the head nominal in the matrix clause. This marker is mandatory. In RCS, the alignment is nominative-accusative, as the marker $=m a$ is used when the head nominal is the $S$ as in (20) or the possessee as in (21) in the matrix clause. The nominative case marker =ma is only used in RCS, which is the reason why it does not belong to the list in (13).

Nominal: Genitive in RC - $\mathrm{s}$ in matrix clause

(20) kwírás yèrhá pèftùs nềímà àkàkíyó tàwàrkrí

$\begin{array}{lllll}{[k w i ?} & \text { as } & \text { ye?-ha } & \text { pef-tus } & n \tilde{a}-\varnothing-i]=m a \\ \text { year one } & \text { small-NMLZ } & \text { POSS3PL-father } & \text { go-S3SG-PST=NOM }\end{array}$

$\begin{array}{ll}a-k a k i=y o & \text { tawar- }- \text {-ir-i } \\ \text { POSs3sG-mother=cOM } & \text { stay-k-S3PL-PST }\end{array}$

'The small boys whose father went out one year ago stayed with his (the father's) mother.' $\{$ Txt $\}$

Nominal: $\mathrm{S}$ in $\mathrm{RC}$ - genitive (possessee) in matrix clause

(21) kèt fàtàyè? pèfó?làkàs ĩ̀nà̀ tfiràmà ồ:nĩ̀
[ket]a ta-ye?
pef-oplak as $\tilde{i}=y \tilde{a}$
yesterday POSS1-small POSS3PL-horse one DEM.PROX $=$ LOC
t $a-i r-w a]=m a \quad \quad \tilde{o}:-n-\varnothing-i$
be_there-S3PL-PFV=NOM sleep-DUR-S3SG-PST
'Yesterday, one horse of my boys who live here died.' $\{$ Txt $\}$

The marker $=r a$ is used when the head nominal is an o in the matrix clause, as in (22). 
Nominal: A in RC - Po in matrix clause

(22) tàsmà kàpàn kàpàn kórtà tayè? kàtfềmirà wífkarí
tas=ma [kapan kapan korta ta-ye?
$\left.\varnothing-k a-t \int \tilde{a}-\varnothing-p i\right]=r a$
$1_{\text {PRO }}=$ TOP morning morning woman POSS1-small O3SG-APPL:R-See-S3SG-FUT=ACC

$\emptyset$-wif-k-a-ri

03SG-give.03-K-S1SG-PST

'I entrusted him to the woman who will take care of my son every morning.' $\{$ Txt $\}$

The presence of internally-headed relative constructions in Pesh is consistent with the verbfinal order language type (Keenan 1985: 163, Lehmann 1986, Basilico 1996). Dryer (2013) shows that in his corpus of 63 languages with IHRCS, 58 languages, that is to say 93\%, are OV. Some counterexamples of the relation between IHRCS and OV constituent order exist in Austronesian languages, such as Tkang Besi, Tagalog or Seediq (Aldridge 2004).

\subsubsection{Position of the Head Nominal}

In Pesh, the IHRC is used when the role of the head nominal in the RC is a core argument or a genitive, as illustrated in (23) for $\mathrm{s}$, in (24) for 0 , and in (20) for genitive.

Nominal: $\mathrm{s}$ in $\mathrm{RC}$ - locative in matrix clause

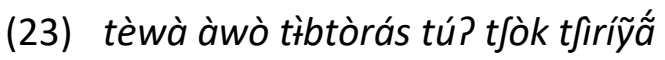

$\begin{array}{lllll}\text { tewa } & \text { awo } & \text { tib-a-tV-i=ras } & \text { [tu? } & \left.\text { t } \int 0 k \text { t } a-i r-i\right]=y \tilde{a} \\ \text { still } & \text { rifle fire-S1SG-NEG-PST=RSN } & \text { DEM.MED } & \text { hill be_there-S3PL-PST=LOC }\end{array}$

'Because I still didn't fire in these hills that were (there).' $\{T x t\}$

Nominal: so in RC - instrumental in matrix clause

(24) tàsmà tàtùs íspáràh tã̀ỹhryó wầrí àmáskárí?

tas=ma [ta-tus isparah ta-ãyh- $\varnothing-r i]=y o \quad$ wãri

$1_{\text {PRO }}=$ TOP POSS1-father machete o1-give.01/2-S3SG-PST=INSTR pig

a-mas-k-a-ri?

O3sG-kill-k-s1sG-PST

'I killed the pig with the machete that my father gave to me.' $\{T x t\}$

The nominal occupies its syntactic position according to its role in the RC. Therefore, the nominal may occur as the first constituent in the relative construction, as in (23), that is to say as the left-most element (Boyle 2016:260). Alternatively, it may have a more internal position, as in (20) or (24). The position is an important parameter but not the most significant. In example (23), the RC includes two constituents, namely the nominal, that is the head and that functions as the $\mathrm{s}$, and the $\mathrm{v}$, so the nominal is the left-most element, in keeping with the verb-final order. Nevertheless, if another element is introduced as a locative constituent, it appears to the left of the RC, as in (25). The relevant feature for analyzing the RC in (23) as an IHRC is, firstly, the syntactic role of the head nominal in the RC and, secondly, the fact that the marker at the end of the relative construction corresponds to the role of the nominal in the matrix clause. The position of the nominal is analyzed as internal even if it occurs on the left. 
Nominal: $\mathrm{S}$ in RC - locative in matrix clause


tewa awo tib-a-tV-i=ras
$[\tilde{a}=y \tilde{a}$
tup tfok
still rifle fire-S1SG-NEG-PST=RSN DEM.DIST=LOC DEM.MED hill
$\left.t \int a-i r-i\right]=y \tilde{a}$
be_there-S3PL-PST=LOC
'Because I still didn't fire in these hills that were there.' $\{$ Txt $\}$

The order within the RC corresponds to a verb-final, more specifically an AOV, constituent order, especially when the referents of the nominal are equal in degree of animacy. When two arguments are encoded by nominals, the nominal that functions as the A occurs before the one that functions as the $\mathrm{O}$ in the RC, as in (26).

Nominal: A in RC - o in matrix clause

(26) árwấ òníh tàkàkì àrkàpáftè?nè̀rírà kàpròháwá

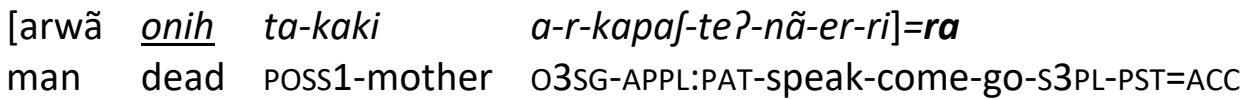

ka-proh-a-wa

O3PL-look_for-s1sG-PFV

'I looked for the dead men who came to speak to my mother and went away.' $\{$ Txt $\}$

In (27), the order is A - so - Po. In Pesh, the strict order means that no ambiguity occurs, unlike what has been reported for IHRCS in other languages (Comrie 1989 [1981]: 146, Keenan 1985: 163).

Nominal: Po in $\mathrm{RC}-\mathrm{s}$ in matrix clause

(27) pà î̀nsi árwã́ kàkàkúhrímà ùwã̀ nẽ̀rí

[pa ĩnsi arwã ka-ka-kuh-u-ri]=ma uwã nã-er-i

$2_{\text {PRO }}$ medicine man O3PL-APPL:R-buy-S2-PST=NOM quickly go-S3PL-PST

'The men from whom you bought the medicine went quickly.' $\{$ Txt $\}$

Some flexibility is possible when the encoding of the arguments is represented by different persons. As Pesh has a strict head-marking pattern, the arguments are encoded in the verb. In (28) the nominal that functions as the primary object, korta 'the woman', occurs before the nominal that functions as the so insi 'the medicine', and before the pronoun that functions as the A tas; but since this is the first person, it is encoded as the suffix $-a$ in the verb. 
Nominal: $\mathrm{PO}$ in $\mathrm{RC}-\mathrm{s}$ in matrix clause

(28) kórtà î̀nsì tàsàkàkáhrímà kúkúrànấ tfúá

[korta insi tas a-ka-kuh-a-ri]=ma

woman medicine $1_{\text {PRO }}$ O3SG-APPL:R-buy-S1SG-PST=NOM

\section{kukura=yã $\quad t \int a-\varnothing-w a$ \\ Moradel=LOC be_there-s3SG-PFV}

'The woman from whom I bought the medicine lives in Moradel.' $\{$ Txt $\}$

In (29), the nominal that is the A of the RC arwã pok 'two men' is postposed to the pronoun of the first person tas that functions as a PO (external possession in this context). As both are indexed in the verb, no misinterpretation is possible.

Nominal: $\mathrm{A}$ in $\mathrm{RC}-\mathrm{s}$ in matrix clause

(29) tàs árwấ pók tàkồ:nìrJómàỹáhaú tèkkrí

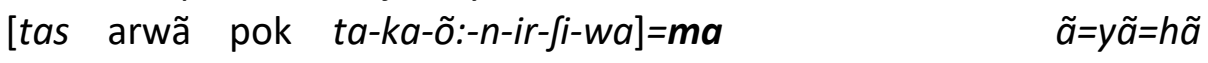

$1_{\text {PRO }}$ man two O1-APPL:R-Sleep-DUR-S3PL-PST.REC-PFV=NOM DEM.DIST=LOC=FOC

te?-k-ir-i

come-k-S3PL-PST

'The two men who died (on me) came here.' $\{T x t\}$

In (30), the order of the nominals that introduce the two objects is reversed: the Po pa 'you' occurs in the front position and the so, the nominal yopra 'cassava', occurs after it. No ambiguity is possible because the $\mathrm{A}$, the first person singular $-a$, and the PO, the second person pi-, are indexed in the verb. Thus the sole reading is that the head nominal yo?ra is the so in the RC and the $s$ in the matrix clause.

Nominal: so in $\mathrm{RC}-\mathrm{s}$ in matrix clause

(30) pà yó?rà pikàkúhápé?kárímà énàrí

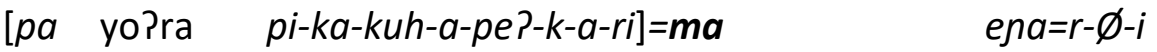

$2_{\text {PRO }}$ cassava O2-APPL:R-buy-S1SG-bring-K-S1SG-PST=NOM good=COP-S3SG-PST

'The cassava that I bought and I brought to you was good.' $\{$ Txt $\}$

In Pesh, in an IHRC the order usually follows the AOV constituent order. The head nominal appears in an internal position and its position usually depends on its syntactic role in the RC. Some pragmatic strategies allow for changing the order of the nominals that function as subject or object, but only if no ambiguity arises.

\subsubsection{Referential Status of the Head Nominal}

Various authors claim that in IHRCS the referential status of the head nominal is indefinite (Cole et al. 1982, Williamson 1987, Culy 1990, Basilico 1996: 507-510, Boyle 2016: 255). For example, Boyle (2016: 255) shows that Hidatsa, like other languages with IHRCS, obeys the indefiniteness restriction first proposed by Williamson (1987) for Lakota. This restriction on the head nominal follows from the quantificational analysis of IHRCS. Williamson claims that indefinites are not quantifiable, that is, they are "quantifier-free," and that quantifiers are excluded as heads because semantically such a quantifier is interpreted as a restrictive term. 
A definite is known and presupposes the content of its predicate. This property is not consistent with the existence of a RC in which the head would be already familiar to the hearer, as further specification by the RC is unnecessary. As a consequence, for these authors, the head of an IHRC can only be indefinite.

The examples in Pesh do not abide by the indefiniteness restriction, since indefinite nominals and definite nominals may be heads in an IHRC. The head nominal may be indefinite, as arwã-s 'a man' in (31), but also definite, as in (32) and (33).

Nominal: A in RC - PO in matrix clause

(31) tàsmà Î́yấ árwấs tayè? kàtfúífmimà wífkarí

tas=ma [ĩ=yã arwã-s ta-ye?

$1_{\text {PRO }}=$ TOP DEM.PROX $=$ LOC man-INDF POSS1-small

\section{$\varnothing$-ka-t $\left.\int u i f-\varnothing-p i\right]=m a \quad \quad$-wif-k-a-ri \\ O3SG-APPL:R-learn-S3SG-FUT=TOP O3SG-give.03-K-S1SG-PST}

'I entrusted him to a man who will teach my son here.' $\{$ Txt $\}$

Nominal: $\mathrm{A}$ in $\mathrm{RC}-\mathrm{s}$ in matrix clause

(32) î̀kìtmà tó?ministro nẽ̀hừmã̀ tè?kwá

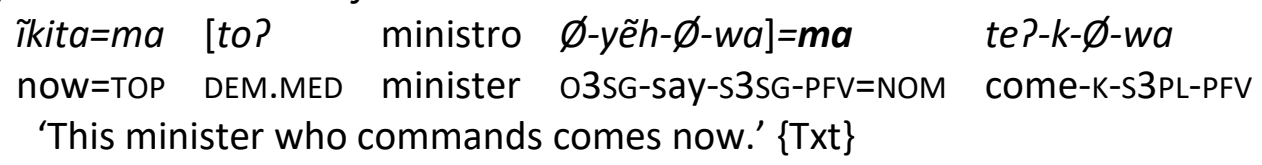

Nominal: $\mathrm{O}$ in RC- $\mathrm{s}$ in matrix clause

(33) tárwấ wáká pók kàkúhímà kà?yèrí

[ta-arwã wakaJ pok ka-kuh- $\varnothing-i]=m a \quad k a$ ?-ye?-er-i

Poss1-man cow two O3PL-buy-S3SG-PST=NOM make-small-s3PL-PST

'The two cows my husband bought gave birth.' $\{$ Txt $\}$

Pesh has an indefinite article $-s$ ' $a$ ', in (31) but does not have a definite article; however, the presence of a demonstrative in (32) shows that the NP is definite. In (33), the definiteness is the result of the pragmatic context expressed in the RC. The two cows are definite and referential cows because they are the two that the husband bought and presented earlier in the story.

\subsubsection{Position of the Enclitic Marker}

In IHRCS in Pesh, a mandatory enclitic marker appears in the final position. This obligation contrasts with the situation in which the enclitic marker is used in an NP where the case marking is optional for subjects and objects and only obligatory for the oblique and adjunct cases in PPs (see Section 9.2.1). This constraint in RCs signals that the clause is subordinated, since a subordinate clause (complement, adverbial, or relative) has an obligatory marker on the predicate, as in (34) for an adverbial temporal clause (see also example (23) for a subordinate of reason). 
(34) àpîfkáwá èyè krámã̀

apif-k-a-wa [Ø-eye $-k$-er-wa]=mã

lie.down-K-S1SG-PFV O3SG-sing-K-S3PL-PFV=when/if

'I go to bed when they sing.' $\{\mathrm{Txt}\}$

In an IHRC, the boundary of the RC and of the relative construction are the same, and the relative construction may function as a core argument, as in (33), or a postpositional phrase, as in (35), in the matrix clause. This is the reason why the enclitic marker always occurs at the right edge of the relative construction, as it is a phrasal enclitic. In example (35), I illustrate the position of the enclitic marker using the double square brackets. When the syntactic role of the head is an oblique or adjunct in the matrix clause, that is, when the relative construction functions as a PP, the corresponding case marker is used: the comitative/instrumental, as in (35) for comitative and (36) for instrumental, and locative, as in (37).

Nominal: A in RC - comitative in matrix clause

(35) ì̀kità árwấ éyềjkwáyó kápàfífkwá

[[ĩkita arwã $\varnothing$-eyẽf-k- $\left.\varnothing-w a]_{R C}\right]_{R . c o n s t r u c t i o n}=y o \quad k a p a f-i f-k-\varnothing-w a$

now man O3sG-sing-K-S3SG-PFV=COM speak-DES-K-S3sG-PFV

'He wants to speak with the man who is now singing.' $\{$ Txt $\}$

Nominal: so in RC - instrumental in matrix clause

(36) ispáràh tã̀yhúríyó kàtũ̀Jkáwá

[isparah ta-ãyh-u-ri]=yo katũf-k-a-wa

machete o1-give.01/2-S2-PST=INSTR work-K-S1SG-PFV

'I work with the machete you gave to me.' $\{T x t\}$

Nominal: $\mathrm{O}$ in RC - locative in matrix clause

(37) î̀kità àsò wàrà tīkèrnấ kitíhéré?

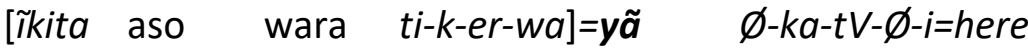

now water green say-K-S3PL-PFV=LOC O3SG-make-NEG-S3SG-PST=MIR

'He made it in the green water as they now call it.' $\{T x t\}$

When the function of the head nominal is the $\mathrm{s}$ or the $\mathrm{A}$ in the matrix clause, the enclitic marker is always the nominative marker $=m a$, as in (38a) and (39a). Use of the ergative case marker =ya with transitive verbs, as in (38b), or the absolutive case marker =ra with intransitive verbs in Carbon variety, as in (39b), is ungrammatical. The requirement to use the marker $=m a$ together with the ungrammaticality of the ergative and absolutive markers in this context shows that the relativization of the subject is related to topicality, as the nominative marker $=m a$ has evolved from the topic marker (Chamoreau 2020b, Shibatani 1991). 
Nominal: $\mathrm{PO}$ in $\mathrm{RC}-\mathrm{A}$ in matrix clause

(38) a. kórtà î̀nsì tàsàkàkáhrímà kètJá kií

$\begin{array}{llll}\text { [korta } & \text { insi } & \text { tas } & a-k a-k u h-a-r i]=m a \\ \text { woman } & \text { medicine } & 1_{\text {PRO }} & \text { O3SG-APPL:R-buy-S1SG-PST=NOM }\end{array}$

ket $a \quad \varnothing-k a-\varnothing-i$

yesterday O3sG-make-s3sG-PST

'The woman from whom I bought the medicine made it yesterday.' $\{$ Txt $\}$

b. * [korta ĩnsi tas a-ka-kuh-a-ri]=ya ketfa $\varnothing-k a-\varnothing-i$

Nominal: so in RC - s in matrix clause

(39) a. pà yó?rà pìkàkúhápé?kárímà énàrí



$2_{\text {PRO }}$ cassava O2-APPL:R-buy-S1sG-bring-K-S1SG-PST=NOM good=COP-S3SG-PST

'The cassava that I bought and I brought to you was good.' $\{$ Txt $\}$

b. * [pa yo?ra pi-ka-kuh-a-pe?-k-a-ri]=ra ena=r- $\varnothing-i$

When the function of the head nominal is the 0 in the matrix clause, two types of enclitic marker are possible. The accusative case marker may be used, as in (40), or the topic marker, as in (41). The reason for the distribution of use of these markers is pragmatic: when the topic marker is used the nominal is topicalized, and when the accusative case is used it is focalized (in the meaning of Lambrecht's focus, 1994). Focalization is the main reason for the use of the accusative marker (see Chamoreau 2021 and Section 9.2.1, a precise study is in progress). In (40), korta 'the woman' marks a selective focus (Chamoreau 2018).

Nominal: A in RC - PO in matrix clause

(40) tàsmà kàpàn kàpàn kórtà tayè? kàtfềmirà wífkarí

$\begin{array}{llllll}\text { tas=ma } & {[\text { kapan }} & \text { kapan } & \text { korta } & \text { ta-ye? } & \left.\varnothing-k a-t \int \tilde{a}-\varnothing \text {-pi }\right]=r a \\ 1_{\text {PRO }}=\text { TOP } & \text { morning } & \text { morning } & \text { woman } & \text { POSS1-small } & \text { O3SG-APPL:R-See-s3SG-FUT=ACC }\end{array}$

$\varnothing$-wif-k-a-ri

O3SG-give.03-K-S1SG-PST

'I entrusted him to the woman who will take care of my son every morning [not another woman].' $\{$ Txt $\}$

Nominal: $\mathrm{O}$ in $\mathrm{RC}-\mathrm{O}$ in matrix clause

(41) kápànùt fà ã̀pàrfimà àsòwáyấ káskírí

[kapani ut]a $\varnothing$-ã-par-fi]=ma aso-ha=yã

morning fish O3SG-eat-S1PL.INCL-PST.REC=TOP water-NMLZ=LOC

$\varnothing$-kas-k-ir-i

O3SG-fish-K-S3PL-PST

'As for the fish we ate in the morning, they fished it from the river.' $\{$ Txt $\}$ 
In this Section, relativization by means of an IHRC has been described as the most frequent and predominant strategy used to relativize nominals that have the role of a core argument or a genitive in the RC. In Pesh, this construction is consistent with the claim that it is common in languages with head-final order (Keenan 1985:163, Dryer 2013). But this construction does not abide by the indefiniteness restriction and the fact that an IHRC has been described as potentially ambiguous.

\subsection{Externally-Headed Relative Clauses Using the Gapping Strategy}

In an EHRC, the head nominal occurs outside the RC. The RC is always postnominal and the external head nominal is represented by a gap marked by _ inside the RC, as in (42).

Nominal: Locative in RC - $\mathrm{s}$ in matrix clause

(42) kàhấ nầpìryã́ pá?k kàhấhí

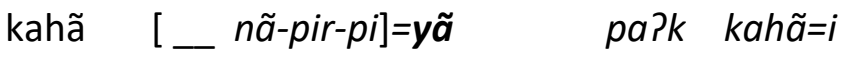

$$
\begin{aligned}
& \text { village go-S1PL.INCL-FUT=LOC lake village=COP.S3SG.PFV }
\end{aligned}
$$

The postnominal position may not be expected as a feature of an OV language. Nevertheless, Dryer (2007:97) notes that among OV languages, postnominal and prenominal orders are about equally common. In the case of Pesh, there are two reasons for this position. First, in an NP, modifiers such as the indefinite article and numeral are postposed (see examples (7) and (8), Section 9.2.1). Second, in an independent clause, the verb is usually postposed. The frequency of final position for verbs is relatively high. A text count conducted on a corpus of texts from five hours of recording revealed that $71 \%$ of the transitive predicates are postposed. In subordinate clauses (complement, adverbial, and relative), the embedded verb occurs at the right edge of the clauses (see example (23)).

In Pesh, an EHRC is used when the head nominal functions as an oblique or adjunct in the RC, as in (42) for locative, in (43) for instrumental, in (44) for comitative, and in (45) for similative or object of comparison. This is an embedded construction, since the nominal forms an immediate constituent with the RC.

Nominal: Instrumental in RC - o in matrix clause

(43) kúkàrskà yè?há tàkiíyó úhàrí

$\begin{array}{llll}\text { kukarska } & {[\text { ye?-ha }} & \text { ta-ka- } \varnothing-i]=\text { yo } & \emptyset \text {-uh- } a-r i \\ \text { hoe } & \text { small-NMLZ } & \text { 01-hit-s3sG-PST=INSTR } & \text { 03sG-hide-s1sG-PST }\end{array}$

'I hid the hoe with which the small boy hit me.'

Nominal: Comitative in RC - $\mathrm{O}$ in matrix clause

(44) árwấ kápàfífkáwáyó kàkòrstá

arwã [_kapaf-if-k-a-wa]=yo $\quad \varnothing$-ka-kors- $t-a-w a$

man speak-DES-K-S1SG-PFV=COM O3SG-APPL:R-write-DUR-S1SG-PFV

'I write to the man with whom I want to speak.' $\{T x t\}$ 
Nominal: Similative in $\mathrm{RC}$ - O in matrix clause

(45) ã̀nã̀ nềhúríkán kàárí

$$
\begin{aligned}
& \text { ãnã [__-yẽh-u-ri]=kan } \quad \varnothing \text {-ka-a-ri } \\
& \text { thus } \quad \text { O3sG-say-s2-PST=SIM O3SG-make-s1SG-PST } \\
& \text { 'I did it in the way you said.' }\{\text { Txt }\}
\end{aligned}
$$

\subsubsection{Position of the Enclitic Marker}

In an EHRC, as in an IHRC, the enclitic is mandatory. This strategy results in an unambiguous RC because the marker is the one that involves the significant semantic information in the RC (locative, comitative, instrumental, similative). The position of the case enclitic at the right edge of the RC is not expected because the enclitic is a phrasal enclitic (see Section 9.2.1). In example (45), if the square brackets of the relative construction were used, the position

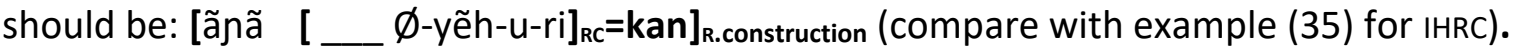

Nevertheless, this position can be explained by three factors. First, the phrasal enclitic is expected to occur in association with the head nominal in the RC. But the representative of the head nominal in the RC is a gap. The enclitic cannot attach to a gap; it needs a distinctive host. For this reason, the enclitic migrates to the right edge of the RC (Weber 1983: 41-46). The use and migration of the case marker result in an unambiguous RC.

The second factor is provided by the deletion of the RC. When the case enclitic corresponds to the syntactic role of the head nominal in the RC, this case enclitic could be deleted. Compare (44) with (46):

(46) árwã́ kàkòrstá

arwã $\varnothing$-ka-kors-t-a-wa

man O3SG-APPL:R-write-DUR-S1SG-PFV

'I write to the man.'

The third factor involves the possibility of a string of enclitics; each enclitic corresponds to a distinctive domain (two enclitics in the same domain, for example two case enclitics, are not possible). The enclitics have a strict order: =case enclitic =topic enclitic.

- The first enclitic is an oblique or adjunct case enclitic. It occurs at the right edge of the $\mathrm{RC}$, where it flags the syntactic role of the head nominal in the RC: locative (47), comitative (48), instrumental (49), or object of comparison (50).

- The second enclitic is the topic enclitic. It occurs at the end of the relative construction and indicates the pragmatic function (topic) of the head nominal in the matrix clause.

Nominal: Locative in $\mathrm{RC}$ - topicalized $\mathrm{s}$ in matrix clause

(47) kàhấ tfà?áríyấmà yè?í
kahã $\left.t \int a-a-r i\right]=y \tilde{a}=\boldsymbol{m a}$
ye? $=i$
village
be there-S1SG-PST=LOC=TOP small=COP.S3SG.PFV
'As for the village where I was born, it is small.' $\{T x t\}$ 
Nominal: Comitative in $\mathrm{RC}$ - topicalized o in matrix clause

(48) kórtà tè?kúríyómà kàhírtáwá

korta $\quad[\quad t e ?-k-u-r i]=y o=m a \quad k a-h i r-a-t V-w a$

woman come-K-S2-PST=COM=TOP O3PL-know-S1SG-NEG-PFV

'As for the the women with whom you came, I didn't know them.' $\{T x t\}$

Nominal: Instrumental in RC - topicalized s in matrix clause

(49) kàsúrústà sìrà tásbèrfiyómà tò̀fkí

kasurusta $[$ sira _ $\varnothing$-tas-ber-fi $]=\mathbf{y o}=\mathbf{m a}$ tõ $f-k-\varnothing$-i

knife food O3SG-cut-S1PL.EXCL-PST.REC=INSTR=TOP disappear-K-S3SG-PST

'As for the knife with which we cut the food, it disappeared.' $\{T x t\}$

Nominal: Similative in $\mathrm{RC}$ - topicalized A in matrix clause

(50) yùkú kàtùhúkánmà tàhtétwá

yuku $[\ldots \varnothing-k a-t u h-u-w a]=k a n=m a \quad$ ta-hte- $\varnothing-t V-w a$

meat O3SG-APPL:R-cook-S2-PFV=SIM=TOP O1sG-like-s3SG-NEG-PFV

'As for the meat the way you cook it, I don't like it.' $\{$ Txt $\}$

\subsubsection{Constraints on the Role of the Head Nominal in the Relative Clause}

In EHRCS, the head nominal functions as an oblique or adjunct in the RC, as in (42) for locative, in (43) for instrumental, in (44) for comitative, and in (45) for similative or object of comparison. In the matrix clause, the head nominal functions most frequently as a subject, as in (42), or an object, as illustrated in (43), (44), and (45). The fact that the head is predominantly a subject or an object in the matrix clause is probably a consequence of the optional case marking attested in the language for arguments and the absence of a genitive case marker (see Section 9.2.1). The head nominal can also function as a locative in both the $\mathrm{RC}$ and the matrix clause, as in (51).

Nominal: Locative in RC and in matrix clause

(51) sũ̀ếsmà àsò wìã̀ úrìs tfirúyấ nàstìrí

sũẽs=ma aso [wifã uris _ t ta-ir-wa]=yã nast-ir-i

donkey=TOP water fish many live-S3PL-PFV=LOC jump-S3PL-PST

'The donkeys jumped in the water where many fish were.' $\{\mathrm{Txt}\}$

When in both the RC and the matrix clause the oblique or adjunct function of the nominal is anything other than locative, a relative construction is never attested. The two clauses are linked paratactically, as in (52) and (53).

(52) tàù̀nyó kàpáfkárí? î́yó tè?kí

$\begin{array}{llll}\text { [ta-aũna=yo } & k a p a f-k-a-r i P] & {[\tilde{I}=\text { yo }} & t e ?-k-\varnothing-i] \\ \text { POSs1-woman's_sister=coM } & \text { speak-k-s1SG-PST } & \text { DEM.PROX=COM } & \text { come-k-s3SG-PST }\end{array}$

'I spoke with my sister, I came with her.'

Intended meaning: 'I came with my sister with whom I spoke'. 
(53) pràwàmà àt fáháyấ tfirí pàkũ̀ ấyó káàrí

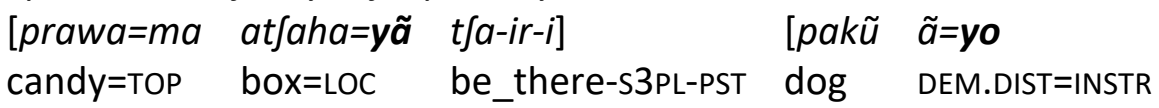

$\varnothing$-ka-a-ri]

O3sG-hit-s1sG-PST

'The candies were in the box, I hit the dog with it.'

Intended meaning: 'I hit the dog with the box where the candies were'.

In this Section, relativization by means of an EHRC has been described as a strategy used when the syntactic role of the head nominal in the RC is peripheral (adjunct or oblique). The head is usually a subject or an object in the matrix clause and may also have a locative role in the matrix clause, showing the specificity of this role.

\subsection{Relative Constructions Introduced by a WH-Word}

The relative constructions with a WH-word that functions as a relative pronoun are only used in the locative role. They are used in various villages but are uncommon.

\subsubsection{The WH-Words Piah 'WHERE' and Pikan 'Where, in which Direction'}

In this strategy, the head nominal occurs outside the RC, and is taken up inside the RC by means of the WH-words piah 'where' or pikan 'where, in which direction' that play the semantic role of the head in the RC. These WH-words function as relative pronouns. This type of RC is less common, as it only occurs when the head nominal has the syntactic role of a locative adjunct within the RC. The WH-word piah 'where' is formed by the verb pi 'place, put down' and the nominalizer -ah, as in (54), and the WH-word pikan (or the dialectal variant piken) is formed by the verb $p i$ and the case maker =kan 'similative', as in (55).

Nominal: Locative in $\mathrm{RC}-\mathrm{O}$ in matrix clause

(54) kètfá tàkà?ó piáh tàs tfà?árísrí ttầbrí

ketJa ta-ka?o [pi-ah tas t tfa?-a-ri=sri

yesterday poss1-house place-NMLZ $1_{\text {PRO }}$ be_there-S1SG-PST=UNCRT

$\varnothing$-tfã-ber-i

O3SG-see-S1PL.EXCL-PST

'Yesterday, we saw the house where I was perhaps born.' $\{T x t\}$

Nominal: Locative in RC and in matrix clause

(55) tàpàtjà kú?kàkáyấ pìkén tJè?èríkén tèkkrí

ta-patja ku?k aka=yã [pi=ken $t$ t tar-er-i=ken]

POSs1-man's_sister earth big=LOC place-SIM be_there-S3PL-PST=DBT

te?-k-ir-i

come-k-s3PL-PST

'My sisters came from the big land where they (possibly) lived.' $\{T x t\}$ 
The WH-word always occurs at the beginning of the clause and indicates the role of the head nominal within the RC, as in (54) ka?o 'house' and in (55) kupk aka 'big land'. If the head functions as a locative in the matrix clause, the case marker occurs after the head nominal, as in (55). This type of RC is always postnominal and is embedded, as the head nominal forms an immediate constituent with the RC.

When the head nominal is locative in the RC and in the matrix clause, the external head nominal is flagged by the locative case. This feature distinguishes this type of RC from the EHRC, where it is impossible for the locative case to mark the external head nominal. Compare (55) with (51).

The WH-word that functions as a relative pronoun pronominalizes the whole locative nominal and has a clause-initial position that does not represent the prototypical position occupied by the adjunct phrase in a simple clause. Comparing (54) with (56), we observe that the fronting of the constituent that indicates the locative role leaves a trace in the original position (Comrie 1998: 64-67), marked by $t$ in (54) and (55).

(56) tàs tàkà?óyấ t fà?árí

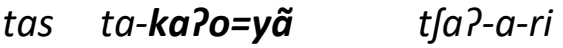

$$
\begin{aligned}
& 1_{\text {PRO POSS1-house=LOC be_there-S1SG-PST }} \\
& \text { 'I was born in my house.' }
\end{aligned}
$$

The relative pronouns are grammaticalized from the WH-word piah 'where', as in (57) and pikan 'where, in which direction' as in (58). From the 18 elements used as WH-words found in Pesh (Chamoreau 2020a) piah 'where' and pikan 'where, in which direction' are the only two that are used in a headed relative construction.

(57) piáh nềrísà

$$
\begin{array}{ll}
\text { pi-ah } & \text { nã-er-ri=sa } \\
\text { place-NMLZ go-S3PL-PST=WH } & \text { 'Where did they go?' } \quad\{\text { Txt }\}
\end{array}
$$

(58) pikán pitùswá nềisà

$$
\begin{array}{lll}
\text { pi=kan } & \text { pi-tus-wa } & n \tilde{a}-\varnothing-i=s a \\
\text { place=SIM } & \text { POSs2-father-2PL } & \text { go-s3sG-PST=WH } \\
\text { 'Where (in which direction) } & \text { did your father go?' }\{\text { Txt }\}
\end{array}
$$

\subsubsection{The Subordinator}

In a RC introduced by a WH-word, the verb is obligatorily marked by a subordinate marker. These subordinators indicate the status of syntactic dependence of the RC in relation to the matrix clause. Three subordinators have been attested: the subordinator $=s r i$ in (54), which semantically conveys the state of affairs as uncertain; the dubitative subordinator $=k a n$ (or dialectal =ken) in (55); and the subordinator =ma in (59), which conveys certainty. These subordinators are encliticized on the verb. The difference between these enclitics corresponds to the degree of probability that the event described in the proposition will happen or has happened (Chamoreau 2020a). 
(59) tàkà?ó piáh t tà?árímá àhíráwá

$\begin{array}{llll}\text { ta-ka?o } \quad[p i-a h & \left.t \quad t \int a \text { P-a-ri=ma }\right] & a-h i r-a-w a \\ \text { POSS1-house place-NMLz be_there-S1SG-PST=CRT } & \text { o3sG-know-S1SG-PFV } \\ \text { 'I know the house where I was born.' }\{\text { Txt }\} & \end{array}$

The subordinator =sri indicates uncertainty and may be translated in English by including 'perhaps' in the clause. The subordinator =kan is grammaticalized from the similative enclitic =kan (see Section 9.2.1 and Chamoreau 2017b: 331-335, Chamoreau 2020a). Compare the use of the similative enclitic in an EHRC in (45) and (50). In (45) and (50), the meaning is of similarity (or object of comparison) and the marker functions as a phrasal enclitic. In a subordinate clause, the marker is grammaticalized, with the meaning of doubt or weak possibility, as in (55) and (60).

Nominal: Locative in $\mathrm{RC}-\mathrm{O}$ in matrix clause

(60) kàhã pikán nèikán àhírtáwá
kahã [pi=kan t na- $\varnothing-i=k a n] \quad a-h i r-a-t V-w a$
village place=SIM go-S3SG-PST=DBT O3sG-know-S1SG-NEG-PFV
'I didn't know the village to where he possibly went.' $\{$ Txt $\}$

The certainty marker $=m a$ as in (59) is related to the topic marker $=m a$ in an NP, as in (10) and (18). Topic and certainty markers share the same characteristic of introducing a given or actualized participant or event (Chamoreau 2020b).

In this Section, RCS introduced by a WH-word that functions as a relative pronoun have been described as a strategy - distinct from IHRC and EHRC structures - using a WH-word at the beginning of the $\mathrm{RC}$, in which the verb is marked by a subordinator. This is the sole role that is expressed by two strategies in Pesh, perhaps because RCs with the locative are more commonly used than RCs with other adjunct roles.

\subsection{Pesh: A Predominantly Internally-Headed Relative Clause Language}

In this chapter, I have described the three strategies of headed restrictive relative constructions in Pesh, showing that these three types are not used to the same extent in the language. In Pesh, the syntactic role of the head nominal in the RC is important for distinguishing the three types of restrictive relative construction. Pesh is a predominantly internally-headed RC language: this is its primary and most frequent strategy, because it is used when the head corresponds to a core argument or a genitive in the RC. In Pesh IHRCS are consistent with the different features known to describe this type of construction except for the indefiniteness restriction, since indefinite and definite nominals may be heads in the IHRC. In contrast, EHRCS and WH-RCS are less frequent, as they are used when the head corresponds to a peripheral function in the RC. RCS introduced by a WH-word are the least frequent as they are only used in the locative role. EHRCS are more frequent than WH-RCS but less so than IHRCS. EHRCS are used when the head corresponds to an adjunct or an oblique role, such as the instrumental, comitative, locative or object of comparison.

If we momentarily exclude WH-RCS, we observe that IHRCS and EHRCS have a complementary distribution. This process may be the consequence of the optional case marking attested in the language for arguments and the absence of a genitive case marker 
(see Section 9.2.1). In IHRCS, what is important is to mark the syntactic role of the head nominal in the matrix clause (obliques, adjuncts or arguments), but not in the RC: as this is an argument or a genitive, a marker is optional. In contrast, in EHRCS the information to be highlighted is the syntactic role of the head in the RC (obliques, adjuncts or arguments) because the head appears outside the RC. The language has found strategies for marking the syntactic roles that carry the necessary information for avoiding misinterpretation. As in the case of WH-RCS, this strategy is only used for the locative. Relative constructions for the locative role show a specific position in different systems (see Chapter 1 in this volume).

The compulsory use of a marker at the end of the verb for RCs introduced by a WHword, at the right edge of a RC for EHRCS, and at the right edge of a relative construction for IHRCS shows clearly that the construction is always subordinated. The presence of the marker is obligatory and is analyzed as a specific constraint on subordinating these clauses. In all the RCs in Pesh the verb is finite, since the verb is marked for both arguments and tense and aspect, and it may be a complex serial verb, as in (61) for an IHRC. These verbal characteristics are associated with finiteness features.

Nominal: $\mathrm{s}$ in $\mathrm{RC}-\mathrm{O}$ in matrix clause

(61) árwấ òníh tàkàkì àrkàpáftè?nềrírà kàpròháwá

[arwã onih ta-kaki a-r-kapaf-te?-nã-er-ri]=ra

man dead POSS1-mother O3SG-APPL:PAT-speak-come-go-S3PL-PST=ACC

\author{
ka-proh-a-wa \\ O3PL-look_for-s1sG-PFV \\ 'I looked for the dead men who came to speak to my mother and went away.' $\{T x t\}$
}

Nevertheless, in this language, two different degrees of finiteness exist: RCs introduced by a WH-word have a higher degree of finiteness, as the subordination is marked by the presence of the relative pronoun and a subordinator at the end of the verb, while IHRCS and EHRCS have a lower degree of finiteness, since the nominal character of IHRCS and EHRCS may be inferred from the presence of case or topic enclitics, usually used in NPs and in PPs. This type of lower degree of finiteness or grammatical nominalization may be defined as a syntactic process "via which a finite verbal clause ... is converted into a noun phrase" (Givón 2016: 272). Finiteness is evaluated on the relative construction, not only on the verb or on the RC (Chamoreau \& Estrada 2016).

The present study provides a first analysis of RCs in Pesh, in particular the relevance of internally-headed relative constructions, but it is also an invitation to continue studying this type of construction in the indigenous languages of Mexico and Central America.

\title{
Acknowledgments
}

The data presented here are part of the Major Documentation Project MDP0276, "A crossvarietal documentation and description of Pesh, a Chibchan language of Honduras" (https://elar.soas.ac.uk/Collection/MPI1050997) funded by HRELP (The Hans Rausing Endangered Languages Programme). I am greatly indebted to the HRELP for their financial support. I extend my deepest thanks to all my consultants: this research would not have been possible without the support of Juana and Francisco Hernández, Ángel and Hernán Martínez, Danilo Lugo, Nimer López, and all our Pesh hosts. Special thanks for their detailed 
and insightful comments to Enrique Palancar, Roberto Zavala Maldonado, Judith Aissen, Eladio (B'alam) Mateo Toledo, and the participants in the workshop of the PICS "Mesoamerica and the syntax of the RC" in San Cristobal de las Casas in September 2015. Specific thanks go to Bernard Comrie, Tom Givón, Roberto Zavala Maldonado, and Enrique Palancar for comments on earlier versions of the chapter and to Timothy Feist for proofreading the English language.

\section{BIBLIOGRAPHY}

Aldridge, Edith. 2004. Internally-headed relative clauses in Austronesian languages, Language and Linguistics 5: 99-129.

Andrews, Avery D. 2007. Relative clauses. In Timothy Shopen (ed.), Language typology and syntactic description, Vol. 2, 206-236. Cambridge: Cambridge University Press.

Basilico, David. 1996. Head position and internally-headed relative clauses, Language 72: 498-532.

Boyle, John P. 2016. The syntax and semantics of internally-headed relative clauses in Hidatsa. In Catherine Rudin \& Bryan J. Gordon (eds), Advances in the study of Siouan languages and linguistics, 255-287. Berlin: Language Science Press.

Chamoreau, Claudine. 2017a. A preliminary grammatical sketch. Report ELDP. August 2017 (ms 158 pp.).

. 2017b. Multifunctionality and polysemy of the similative marker -kán in Pesh. In Yvonne Treis \& Martine Vanhove (eds), Similative and equative constructions: A crosslinguistic perspective, 321-337. Amsterdam: John Benjamins Publishing Company.

. 2018. Constituent order flexibility, differential case marking, and focus in Pesh. Paper presented at the workshop "OV basic word order correlates and information structure," LABEX-EFL, INALCO, SEDYL.

. 2019. Alineamiento escindido en pesh. Invited talk at V Congreso Internacional de ACALING, Universidad Nacional de Costa Rica (UNA), Heredia. 28 August 2019.

. 2020a. Headless relative clauses in Pesh. In Ivano Caponigro, Harold Torrence, and Roberto Zavala Maldonado (eds.), Headless Relative Clauses in the Mesoamerican Languages, 509-546. Oxford: Oxford University Press.

. 2020b. Overt topic marking and discourse coherence in Pesh. Between correlation and divergence. Anthropological Linguistics 61(2):1-30.

2021. Morphological split ergative alignment and syntactic nominative-accusative alignment in Pesh. International Journal of American Linguistics. 87(4). 501-537.

Chamoreau, Claudine and Estrada-Fernández, Zarina. 2016. Finiteness and nominalization: An overview. In Claudine Chamoreau and Zarina Estrada-Fernández (eds), Finiteness and Nominalization, 1-12. Amsterdam: John Benjamins.

Cole, Peter, Harbert, Wayne, and Hermon, Gabriela. 1982. Headless relative clauses in Quechua, International Journal of American Linguistics 48: 113-124.

Comrie, Bernard. 1989. Relative clauses. In Bernard Comrie (ed.), Language universals and linguistic typology. Syntax and morphology, 138-164. Oxford: Basil Blackwell Publisher, 2nd edition.

. 1998. Rethinking the typology of relative clauses, Language Design 1: 59-86.

Comrie, Bernard and Kuteva, Tania. 2005. Relativization strategies. In Martin Haspelmath, Matthew Dryer, David Gil, and Bernard Comrie (eds.), World atlas of language structures, 494-497. Oxford: Oxford University Press. 
Constenla Umaña, Adolfo. 2012. The Chibchan languages. In Lyle Campbell and Verónica Grondona (eds), The indigenous languages of South America: A comprehensive guide, Vol. 2: 391-437. Berlin: Mouton de Gruyter.

Conzemius, Edward. 1928. Los indios paya de Honduras. Estudio geográfico, histórico, etnográfico, y lingüístico, Journal de la Société des Américanistes 20: 253-360.

Culy, Christopher. 1990. Grammatical relations and verb forms in internally-headed relative clauses. In Patrick Farrell, Katharina Dziwirek and Errapel Meijas Bikandi (eds.), Grammatical relations: a cross-theoretical perspective, 83-93. Stanford: CSLI Publications.

Dryer, Matthew. 2007. Word order. In Timothy Shopen (ed.), Language typology and syntactic description, Vol. 1: 61-131. Cambridge: Cambridge University Press.

. 2013. Order of relative clause and noun. In Martin Haspelmath, Matthew Dryer, David Gil, and Bernard Comrie (eds.), The world atlas of language structures online. Leipzig: Max Planck Institute for Evolutionary Anthropology. (Available online at http://wals.info/chapter/90, accessed on 2016-10-22.)

Frank, Paul. 1990. Ika syntax. (Studies in the Languages of Colombia, 1.) Arlington: Summer Institute of Linguistics and The University of Texas at Arlington.

Givón, T. 2016. Nominalization and re-finitization. In Claudine Chamoreau and Zarina Estrada Fernández (eds), Finiteness and Nominalization, 271-296. Amsterdam: John Benjamins.

Holt, Dennis. 1999. Pech (Paya). Munich: Lincom Europa.

Keenan, Edward. 1985. Relative clauses. In Timothy Shopen (ed.), Language typology and syntactic description, Vol. 2: Complex constructions, 141-170. Cambridge: Cambridge University Press.

Lambrecht, Knud. 1994. Information structure and sentence form. Topic, focus, and the mental representations of discourse referents. Cambridge: Cambridge University Press.

Lehmann, Christian. 1986. On the typology of relative clauses, Linguistics 24: 663-680.

McGregor, William B. and Verstraete, Jean-Christophe. 2010. Optional ergative marking and its implications for linguistic theory. Lingua 120: 1607-1609.

Quesada, Diego. 2007. The Chibchan languages. Costa Rica: Editorial Tecnológica de Costa Rica.

Shibatani, Masayoshi. 1991. Grammaticalization of topic into subject. In Elizabeth Closs Traugott and Bernd Heine (eds), Approaches to grammaticalization, Volume II. Focus on types of grammatical marker, 93-133. Amsterdam: John Benjamins.

Silverstein, Michael. 1976. Hierarchy of features and ergativity. In Robert M. W. Dixon (ed.), Grammatical categories in Australian languages, 112-171. Canberra: Australian Institute of Aboriginal Studies.

Weber, David. 1983. Relativization and nominalized clauses in Huallaga (Huanuco) Quechua. Berkeley: University of California Publications.

Williamson, Janis Shirley. 1987. An indefiniteness restriction for relative clauses in Lakhota. In Eric Reuland and Alice ter Meulen (eds), The representation of (in)definiteness, 168190. Cambridge: MIT Press. 